\title{
International Collaborative Experiences to Design Areas Prone to Flood: Intervention in the Southern part of Resistencia (Argentina)
}

\author{
Valeria Schneider $^{1}$, María José Roibón ${ }^{1}$, María Victoria Valenzuela ${ }^{1}$, Julio Borges Nogueira $^{1}$ \\ ${ }^{1}$ Facultad de Arquitectura y Urbanismo (FAU) Universidad Nacional del Nordeste (UNNE), Argentina \\ valeria_schneider@hotmail.com
}

\begin{abstract}
The Brian A. Thomson Institute of Urban and Regional Planning of the Faculty of Architecture and Urbanism of the UNNE (Argentina) and the Jurusan Arsitektur Fakultas Teknik, Faculty of Engineering, Universitas Muhammadiyah Jakarta (Indonesia), have been developing joint activities within approved projects since 2015, as part of a framework of International Cooperation Agreement. Faced with the global context situation due to the Covid19 pandemic, where virtual activities flourished, it was considered an opportunity to bring together teams from both institutions in a joint activity. Therefore, an "International Workshop on Landscape 2020" was formulated to find better design schemes to mitigate the flood in the Southern area of Resistencia city in Argentina by implementing sustainable strategies to design flooding parks for recreational and absorbent purposes. With highly satisfactory outcomes prepared jointly by groups of students from both geographies, with the follow-up of coordinating Lecturers (Facilitators) and the participation of Keynote Speakers, a compendium was made for the formal transfer to the Local authorities, fostering the link between the academic spheres and society through a university extension mechanism. This article aimed to describe the collaborative work process, analyze the implemented methodologies, and lecturers and students' perceptions of this experience.
\end{abstract}

\section{(C) 2021 IJBESR. All rights reserved.}

Keywords: International Workshop, Urban Landscape

\section{Introduction}

The workshop is a technique that allows exchanging different points of view and opinions concerning specific topics to create new criteria or enhance knowledge. In architecture, in urban planning and design, workshops have been used widely to guarantee the involvement of citizens, practitioners, professionals in urban design processes, even though students, in academic terms and with the same purpose.

Therefore, the Workshops can be seen as another tool that could be organized by academic institutions to promote students' participation in and consciousness about urban topics, making revitalization initiatives for inner-city or metropolitan areas.
Currently, the design competition is good to avoid poor schemes by seeking innovative proposals for spatial challenges in heavily populated areas considering issues and needs of existing and future communities. Well-managed competitions have a reputation for giving the best range of design options to choose from at a fraction of the total construction cost of a scheme [1]

This paper, thus, will describe the process undertaken by the International Workshop on Landscape 2020 held in October 2020 by virtual media. The workshop is between students on Landscape of Faculty of Engineering from Jurusan Arsitektur Fakultas Teknik, Universitas Muhammadiyah Jakarta (Indonesia), and students from Architecture of Landscape of Facultad de 
Arquitectura y Urbanismo de la Universidad Nacional del Nordeste (Argentina). The workshop aimed to assess their collaborative experience and contribution.

\section{The Background}

The Institute of Urban and Regional Planning Brian Alejandro Thomson (IPUR-BAT) have been carrying out different activities within Network Projects which gather the University of Rosario, University of Litoral and University of North East from Argentina and Universitas of Muhammadiyah, Jakarta (Indonesia), and Mutual Understanding Agreement between UNNE (Chaco-Argentina) and UMJ (Indonesia)

In 2017 within the framework of the "Seventh International Seminar on Urban Policies, Land and Environmental Management for Local Development" and Network Project "Revitalization Policies and Metropolitan Areas: new challenges in the planning process to cities in Argentina and Indonesia," which gather University of Rosario, University of Litoral and University of Nordeste from Argentina with Universitas of Muhammadiyah, Jakarta (Indonesia). The same year, the Urban and Regional Planning Institute, Brian Alejandro Thomson (IPUR-BAT) has been invited to the International Workshop in Indonesia through the participation of lecturers and students.

Therefore, the researchers and lecturers from the Institute of Urban and Regional Planning Brian Alejandro Thomson (IPUR-BAT) organized the first "Ideas Competition on Urban Design in the Northern Area of Resistencia-Chaco." The event was launched only for students of 5th year studying the Subject Urban Development II in the current academic year, with no age limit, free entry, and participants also must be enrolled in Architecture Faculty at UNNE. The assignment focused on designing an "urban project for Facundo Quiroga Car Corridor." [7]
The rewards had different scales. The first best design project allowed two students to attend the International Workshop in Urban Planning and Community Development (IWUPCD) held in Jakarta (Indonesia) in September 2017. The second reward allowed two students to attend the Bienal of Architecture held in Buenos Aires during October, and the third reward consisted of money for prints out of draws designs. Both Faculties have published the research findings in different books, Journals, and Proceedings Department of Architecture Faculty of the Engineering University of Muhammadiyah Jakarta and in various local and Indonesian newspapers.

Furthermore, within the framework of both the major research project "Metropolization Process of the Greater Resistencia. Policies and Strategies", and the collaboration and Transfer Agreement with the Provincial Water Management Authority of urban vacant land as potential green spaces for the optimization of the storm drainage system in the city of Resistencia. Management proposals and feasible regulations". Two key sectors were identified in the Southern of Resistencia through these research outcomes, suffering constant flooding in rainy periods. Moreover, the phenomenon can be alleviated by implementing sustainable strategies based on natural resources and the design of flooding parks, collaborating with the retention of rainwater.

\section{The Workshop on Landscape 2020}

The city of Resistencia is the capital of Chaco the Province, located in the Northeast of Argentina. Corrientes, capital of the homonymous province, integrated a population core with about 1 million inhabitants, becoming the essential conglomerate in the Region.

The city of Resistencia is the capital of Chaco the Province, located in the Northeast of Argentina, together with Corrientes, capital of the homonymous province, integrated a 
population core with about 1 million inhabitants, becoming the most important conglomerate in the Region.

Resistencia is placed in a flooding plain of two Rivers: Paraná and Negro, most of the city is overlapped at North with a fluvial-lacustrine system of Negro River and the South with Arazá Streams, forming an urban interface between unique landscape, valuable wetlands, and flood valleys, leading disordered occupation and environmental quality deterioration.

The mentioned rivers trace a morphology of pronounced meanders that eventually emerge from the main course to form the lagoons that we can find in the city. Unlimited environmental and landscape richness, they are also fragile and sensitive areas. Progress has been made in land policy that considers it necessary to beat nature, filling them and promoting the establishment of informal settlements on its public borders, with the consequent situations of environmental and social vulnerability; as well as with the loss of their benefits as natural reservoirs and green open space [2].

Despite the mentioned issues, to prevent further spread over the valuable landscape, the urban area has RAMSAR Status and, the Government has been formulated Flooding Regulations, implemented through Water Management Authority, Resolutions \# 121/2014 to prevent rainfall and 303/17 from preventing river flooding, to address proper land use in a flooding plain.

The Arazá Stream, a vital watercourse, is a collector from the southern basin of the Greater Resistencia Metropolitan Area, which has been a natural limit for the urban area for decades. Nonetheless, after successive official public and private interventions, it produced a huge decay that characterizes the current site. Derivations, channelized, construction of dwellings, as occupations of the riverbanks and even the riverbed itself, let the stream be incorporated into the urban structure without adopting any necessary hydraulic precautions.

In this context, flooding due to rainfall occurs frequently and has been exacerbated during recent decades, consequently the climate change and the inefficient network of a rainstorm in the city.

According to the New Urban Agenda launched in the ONU- Habitat 2016 event (6), it promoted the "construction of a resilient city, capable of resisting and recovering from human, social and environmental risks, minimizing the impact and vulnerability citizens," among other aspects. Therefore, the Steering Committee's main objective is to encourage proposals aimed at modifying the current situation within the framework of sustainable development by encouraging people to live in harmony with nature and improve their quality of life.

Therefore, public spaces are essential tools for sustainable urban planning. In other terms, vacant public spaces are considered key elements for urban intervention since they organize the land and provide environmental and social benefits to the population [3]. They can contribute by providing environmental and social benefits to the population, playing a key role within integrated water systems [4], addressing the rainfall excesses to green open spaces, alleviating situations threatened by the increase of waterproofing in urban areas.

It is possible to take advantage of the wide variety of green open spaces, feasible to be incorporated into an integrated ecological water system. It would allow it to work as a drainage support during significant rainfalls and find solutions to alleviate water situations that may arise from increased waterproofing in urban areas. 
In this context, the Landscape Architecture Subject from FAU-UNNE (Argentina), in collaboration with the Landscape Subject from UMJ (Indonesia), proposed a joint approach to this urban problem seeking to promote urbanenvironmental strategies and physical planning aimed at achieving better land use and management of urban and natural resources for our cities.

Public open space is a key issue in this process, possibly the engine of an urban change that implies conserving the natural environment. Addressing the water restrictions of the area, considering sports-recreational pathways that reflect the city's cultural identity would lead to the linkage of livable spaces.

The reasons as mentioned earlier encouraged to organize The International Workshop, aimed to involve the Students of Landscape Architecture and Landscape Subjects, tackling design proposals of the urban landscape, and taking into account the natural environment as a floodable park to address the rainfall excesses of the urban area.

The proposals focused on designing green open spaces considering the watercourse of Arazá stream. Despite the urban pressure, the Stream persists along its path and has become one of the leading natural drains in the sector. Likewise, it was relevant to encourage the use of urban-landscape resources within the Designated Area, while considering uses, amenities, and urban furniture for the sector.

Furthermore, the outcomes of this experience could be helpful for Local Authorities and Provincial Government since the land of the Former Federal Shooting Field, sector \# 215, are about to be urbanized with specific projects.

Finally, the flooding park would help mitigate overflows during rainfall events, facilitate the surface runoff, and introduce leisure and sports activities that may link the citizen with the natural hydric landscape.

\section{Objectives}

- The creation of flood-prone urban parks to mitigate overflows in rainfall events and to facilitate surface runoff, as well as considering other activities such as leisure, sports, linking the citizen with the natural landscape.

- The re-link of the Arazá small streams with the city's drainage system, considering two channels: Soberanía, Quijano, and \#16.

- The recovery of the natural landscape of streams areas, as part of the systems of wetlands

\section{Material and Methods}

The Workshop involved:

- Several coordination activities, timelines, and preparation of keydocument with " The Assignment Guidelines " containing key strategies to be considered by groups of students such as objectives.

- Design aspects to be considered.

- Presentation guidelines and elements of delivery.

- Schedule of the competition and day of submission.

- Awards ceremony.

- Attached documentation like backgrounds.

\section{The Designated Area:}

The Chosen Area is located in the Southern sector of Greater Resistencia (Chaco, Argentina). The intervention sector extends to sectors \# 211 and \#215, classified as Severe Risk Area by the Provincial Water Management Authority. All kinds of urban occupation on its riverbed are banned (Regulation \#303/17) [5]. (5)

These two farmlands through which the Arazá stream runs are channeled and piped as it passes through the urban footprint. The Arazá Stream resumes its naturalness in the mentioned 
sectors. The watercourse presents little flow in times of drought, though in rainy periods, it acts as the main drainage of the southern region. Although the stream has been affected by urbanization (settlements, sewage, garbage dumps, among others), it still conserves native vegetation, such as trees, marsh, and floating. The watercourse is accompanied by permanent wetlands and conserves certain native forest species. The river-lake landscape, although very damaged and rundown, remains in place.

Sections \# 211 and \# 215, involving about 2 $\mathrm{km} 2$, are classified by the Provincial Water
Management Authority as Severe Risk Area, in which all kinds of urban occupation on its riverbed are banned (Regulation \#303/17) [5]. (5)

Even though the sector undergoes a significant transformation due to the existence of informal settlement stretches of the Arazá stream, the provincial government is promoting the area's urbanization, which leads to the reason why the outcomes of this event may be of great relevance.

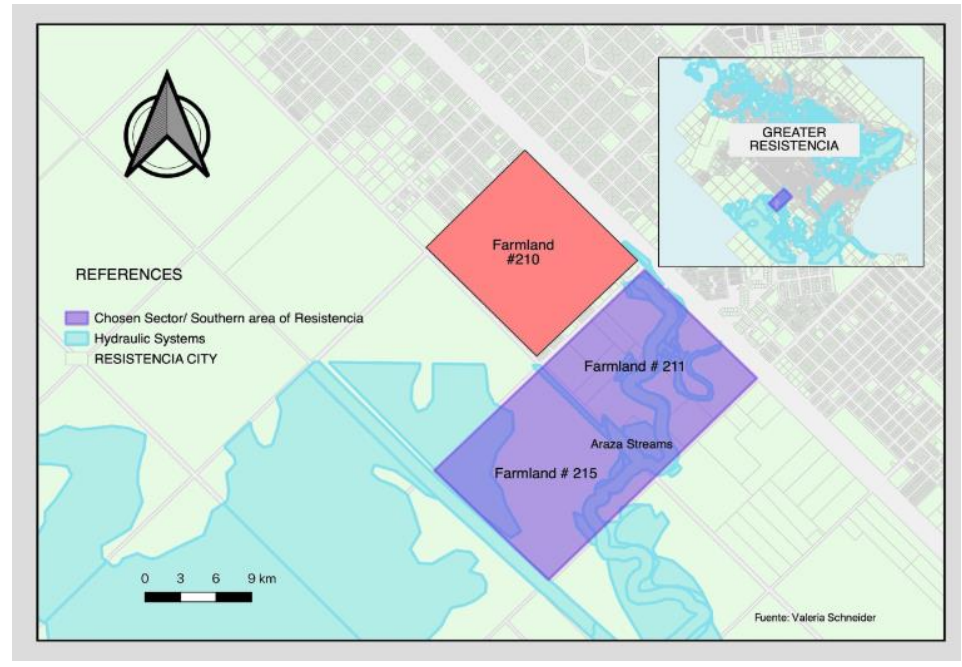

Source: [7]

Figure 1. Designated Area in Southern Resistencia city (Argentina).

\section{Strategies implemented:}

The Workshop was organized by a Steering Committee integrated by Landscape Subject of the UMJ-Indonesia and Subject of Landscape Architecture from The Faculty of Architecture and Urbanism (UNNE). The event was streamed through the FAU Social Media tool between October 20th and 30th, 2020; as well as it was held a competition for design proposals.

Students from both Universities integrated each team. However, they were from different academic levels, from UNNE were part of 5th year and from UMJ were from 3rd year. The Facilitators decided to encourage them to tackle different scales. The UNNE undertook the Master Plan at an urban scale, and students from UMJ launched the proposals of the park in detail. The organizers thought to deliver different lectures recorded and uploaded at the classroom official platform to address the students.

As a result, each team prepared their proposals considering design criteria, activities, amenities, urban furniture, and services. Some examples are listed below: 


\section{Design Criteria:}

- Sustainable design: Ecological concepts, techniques, or processes applied to the design that allow taking advantage of natural resources.

- Lowest environmental impact: Use the natural conditions of the chosen area, avoiding structural modifications of the landscape.

- Design factors: formal consistency, space composition, proposal strength, and spatial structure, design main-idea, among others.

- Urban area and linkage with the city: Strategies that allow incorporating the proposal into the city and accessibility of neighbors and citizen

- Green Open Spaces: to design different scales of open spaces such as pedestrian paths and recreational areas for leisure and sports. The design must also consider urban furniture and any strategy that could be relevant to promote the use of public space and sustainable mobility.

- Cultural and Recreational activities: spaces foreseen for recreational purposes such as open spaces; free use for informal cultural activities, nodes, lakes, areas for public events and community meetings; sidewalks, landmarks, water mirrors, and areas with a wide flexibility of use.

- Sports activities: design lanes for sports like bicycles, skaters, running, walking, and playground areas. Any activity take place in open spaces for practicing activities that require effort, sports that do not involve professional training such as sidewalks for aerobic exercises, or suitable for rollers, bicycles, and skates, playground sectors, and areas for sports with kind of special equipment and sectors for free play

- Food amenities (food trucks, farmer's markets, food shops, picnic areas, etc.)

- Temporal Exhibitions spaces: Crafts and folk carnivals

- Parking Zone: Absorbent and shaded surfaces are preferred. The location of these areas will rely on the proposal. The designers must consider the compatibility with other sectors, the intensity of land use, and the level of natural soil intervention.

\section{Results and Discussions}

\section{The Worksop:}

The "International Workshop on Landscape. Intervention on Southern Area of Resistencia", organized by the Faculty of Architecture and Urbanism, Universidad Nacional del Nordeste in collaboration with The Universitas Muhammadiyah Jakarta (UMJ), declared "Event of Interest" both by FAU-UNNE Resolution \# 249/20 and by "City Council" Resolution \# 025/20.

Implemented by virtual tools, from today until 23rd (Argentina) and 24th of October (Indonesia), Students and Facilitators have had a meeting, group discussion, answering questions at $9 \mathrm{pm}$ (Argentina) and $7 \mathrm{am}$ (Indonesia). The deadline Submission was arranged for 26th of October 2020, 9 pm (Argentina) -and 27th of October 2020 at 7 am (Indonesia). Following that, the Jury has had two days of assessment and discussion.

Finally, the Jury defined the three best proposals to be awarded on the 29th of October 2020. The Closing and Award Ceremony was held at 9 pm (Argentina and 30th of October 2020 at 7 am (Indonesia) by virtual media, the academic authorities, facilitators, members of the Jury, and students were part of the Award Ceremony with the sponsors of each University, broadcasting on live, streaming by the Facebook official webpage of FAU-UNNE. The outcomes of this Workshop have produced 21 (twenty-one) panels, consisting of identification of the site and issues (sector \#211 and \#215, Resistencia), analysis of the physical and non-physical condition of the site, and the proposed design responding to the site. 


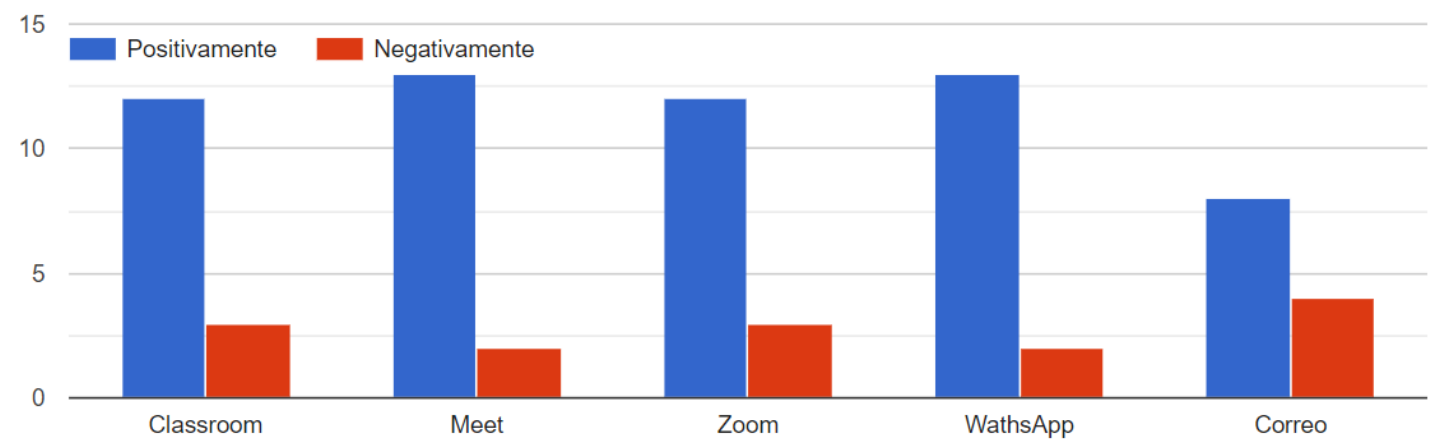

Source: self-elaboration based on survey

Figure 2. Technology support

Finally, the Steer Committee decided to Transfer the outcomes to Resistencia City Council to contribute to better development of the city.

On the other hand, to assess the Workshop's outcomes, the Steer Committee decided it carried out a Survey defining specific questions to students. This was central to have relevant stuff of the experience, leading each Faculty to survey their students.

\section{The Assessment}

Therefore, the survey was used to evaluate what was done and the opinion of the participants. The answers were anonymous, with closed and open questions designed by both universities' organizers to give students free opinions.

This task was not easy since the goal was to reflect collective thinking, which could be helpful to redefine upcoming events with proper methodology. Although mass media technology was the key tool that allowed to perform the event during the lockdown as a result of the Covid pandemic, the survey offered relevant information regarding different choices, reflecting the most suitable options to complete the assignment by considering each group and their possibilities. In this way, the assessment of mass Media tools most helpful is summarised in Figure 2.

For organizers, lecturers and facilitators, it was essential to determine if the methodology applied to encourage the students was suitable for the assignment. Considering each team was integrated by mixed students, addressed by facilitators from both institutions that were randomly designated and considered the possibilities of communication in different languages. The surveys showed the relevance of facilitators' support, both from communication, dynamics, organization, and knowledge support, guidance on key features of urban space, and project definitions. Another vital issue to assess focused on lectures as support for the design proposals, related to theories and concepts aspects of the land, resources of the native landscape, the hydraulic issues and its consequences, different design approaches applied to landscape and current architecture and urbanism ideas. The Workshop organizers decided the lectures were short and accurate, considering the times of the event and the possibilities of participants. The opinion of students regarding the lectures was positive, where the first three topics could be grouped (appropriate, very useful, less useful) that reached $80 \%$ of the surveyed. 


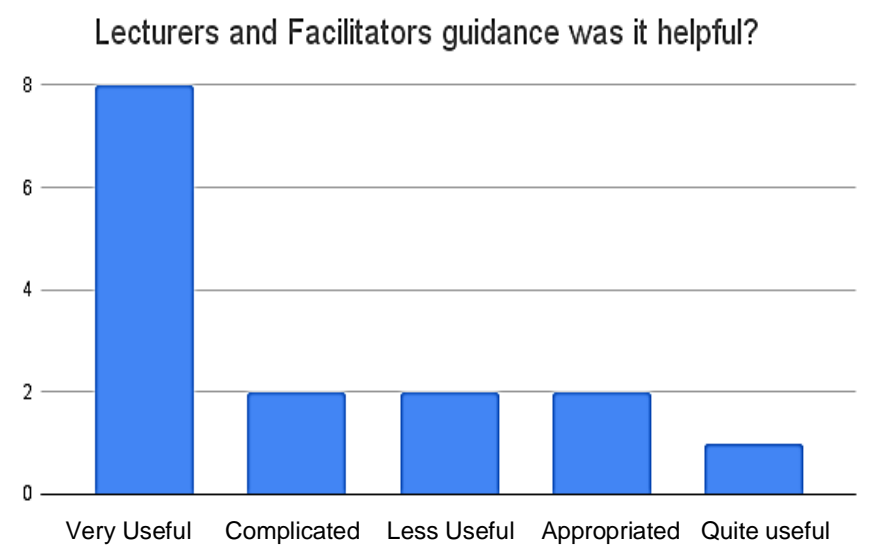

Source: self-elaboration based on survey

Figure 3. Lecturers and Facilitators performance

How would you assess Supporting Lectures?

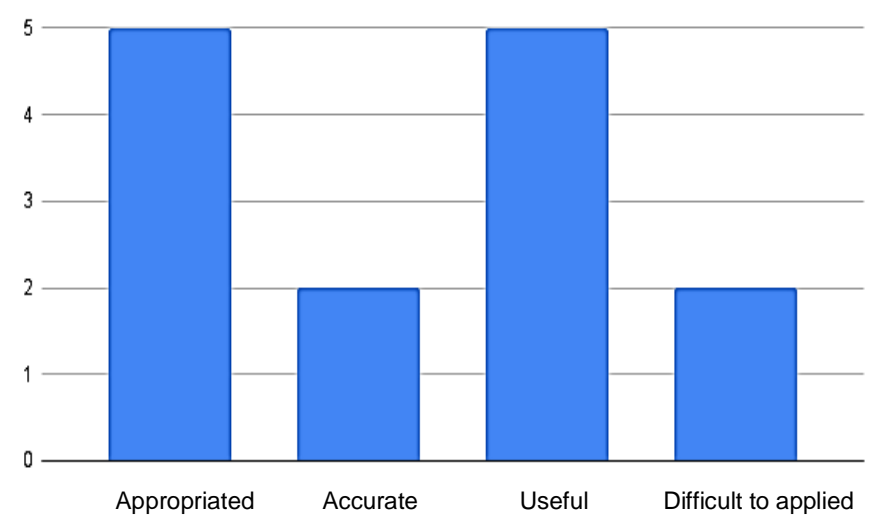

Source: self-elaboration based on survey

Figure 4. Supporting Lectures

The outcomes of this experience were rated through a survey. Most of the students highlighted the experience as positive and very good, considering personal and group growth, despite the difficulties with the language, the cultural exchange took place, which was what they expressed at work". Additionally, from the student's point of view, Workshop offered them:

-To generate a proposal of such magnitude in a reduced time -Meet new classmates and different culture
-The new knowledge and openness of mind -Team design -Collaborate for the critical habitat solution

- It was an excellent opportunity to speak English, "...perhaps the first time I have to speak it to communicate with a person who does not understand my language, I enjoyed it a lot."

-The brief "cultural exchange," but in itself, "...I liked that a lot, listening to other professionals and colleagues from other nationalities, I think it is one of the best experiences you can have" 


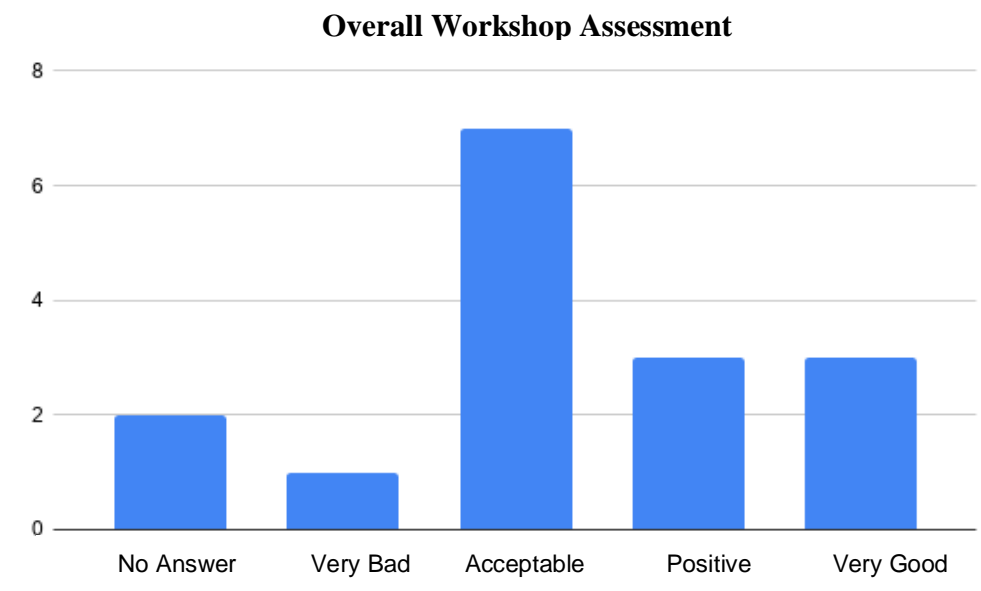

Source: self-elaboration based on survey Figure 5. Overall Workshop Assessment
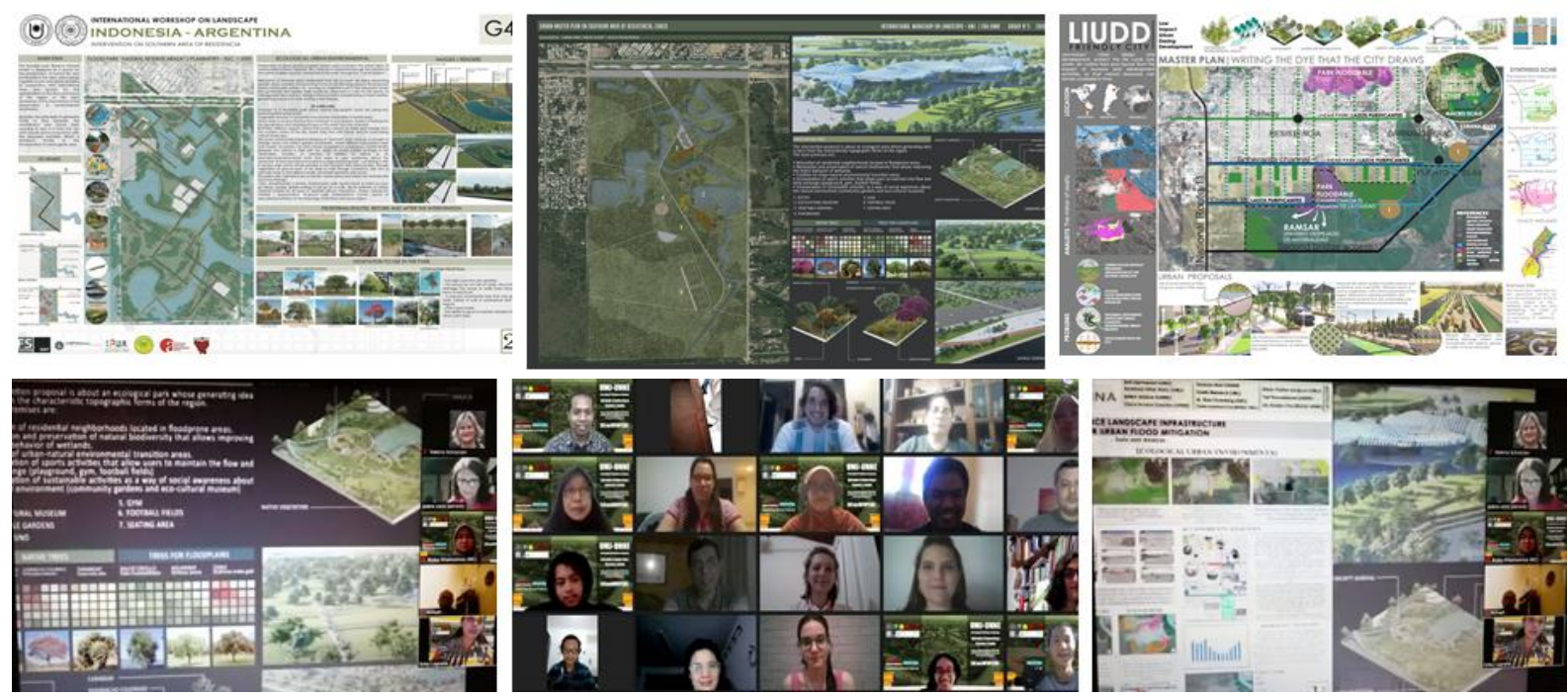

Source: International Workshop on Landscape 2020

Figure 6. Panels submitted and pictures of experience

\section{Conclusion}

The challenge relied upon organizing this event, based primarily on the need to prepare our future professionals to act in increasingly complex and globalized scenarios, deserved the effort made by lectures and colleagues to take advantage of pandemic contexts to generate motivation and spirit of competition.
The outcomes of the assignment offer clear evidence of the student skills to overcome adversity, understand the task to be tackled, exchange ideas, and achieve agreements that they have been able to apply to creative and innovative design proposals. 
Likewise, it is essential to stress the professional job done by Facilitators by addressing their groups; motivating them to apply innovative ideas into a comprehensive design proposal.

The outcomes of this experience were Transferred to Resistencia City Council through a Ceremony with Authorities from Institutions involved, through a Document in Spanish, English, and Bahasa Indonesia approved by Resolution \# 196/2020 of the Academic Board from FAU (UNNE).

Finally, from this experience, new opportunities open to future's joint projects, preparing lecturers and students to open to international agendas above usual LatinAmerican borders.

\section{Acknowledgement}

Special thanks to Authorities and colleagues from Universitas of Muhammadiyah, Jakarta (Indonesia) and authorities from Universidad Nacional del Nordeste for their valuable support.

\section{References}

[1] Fukushirna, Takaki, Kitahara. 2002. Designing The Life In Urban Squares: An Academic Workshop As A Tool For Improving The Quality Of Life In Cities. The Sustainable City II, CA Brebbia, JF Martin-Duque \& LC Wadhwa (Editors). ISBN 1-85312-917-8. 2002 WIT Press, Ashurst Lodge, Southampton, SO40 7AA, UK. All rights reserved. Web: www.witpress.com Email witpress@witpress.com.

[2] Roibón, M., Mahave, A., Zdero, L. 2018. Article "Urban Planning and Projects: Contemporary Public Spaces as Significant Scaffolding in Identity and Heritage in the City". Book of Live the City Congress. Heritage, Cultural Diversity And Identity In The Contemporary City. International Center For Heritage Conservation. CICOP Argentina. ISBN 978-987-4165-03-9
[3] Ruano, Miguel. 1999. Ecourbanism. Sustainable Urban Environments: 60 Projects. ISBN 978-84252-1723-4. Editorial GG. Barcelona. España.

[4] Antoni, Falcón. 2007. Green Spaces For A Sustainable City. Planning, Project, Maintenance And Management. ISBN 27089811. Editorial GG. Barcelona.

[5] Administración Provincial Del Agua. 2019. RESOLUCIONES 121/14 Y 303/17. Recuperado de: http://apachaco.gob.ar/sitio.

[6] UN-HABITAT. (2017). "New Urban Agenda". Hábitat III. United Nations Conference On Housing And Sustainable Urban Development (Hábitat III) held in Quito, Ecuador, October 20th 2016. United Nations publication issued by the Habitat III Secretariat (2017). ISBN: 978-92-1-132736-6.

[7] Schneider, V; Quarin, A.; Miranda,L. 2017."Urban Project Competition in Resistencia (Argentina) and International Workshop in Jakarta (Indonesia). An Overlook of Achievements and Experience, from Lecturer and Students Involved". (2017). Proceedings of International Workshop On Urban Planning And Community Development organizado por Department of Architecture, Engineering Faculty, Universitas Muhammadiyah Jakarta (INDONESIA) Jakarta (Indonesia) entre 18 th to 22 nd of September 2017. ISBN 978-6025428-06- $7 . \quad$ PP 51-62. https://jurnal.umj.ac.id/index.php/iswupcd/article/v iew/2158/181 